\title{
Abelson Virus Abrogation of Interleukin-3 Dependence in a Lymphoid Cell Line
}

\author{
BERNARD MATHEY-PREVOT,,${ }^{1,2}$ GARY NABEL, ${ }^{1,2}$ RONALD PALACIOS, ${ }^{3}$ AND DAVID BALTIMORE ${ }^{1,2 *}$ \\ Whitehead Institute for Biomedical Research, Cambridge, Massachusetts 021421; Massachusetts Institute of Technology, \\ Department of Biology, Cambridge, Massachusetts 02139²; and Basel Institute for Immunology, \\ CH-4005 Basel, Switzerland ${ }^{3}$
}

Received 17 April 1986/Accepted 3 July 1986

\begin{abstract}
Among several tyrosine-protein kinases, only $\mathrm{v}$ - $a b l$ could abrogate interleukin 3 dependence of a lymphoblastoid cell line; v-src and v-fps proteins gave partial or no interleukin 3 independence, respectively. Lymphokine independence was achieved via a nonautocrine mechanism. Direct involvement of $c-m y c$ in this process was not evident.
\end{abstract}

Nonlymphoid hemopoietic cells infected with Abelson murine leukemia virus (A-MuLV) have been reported to lose their requirement for interleukin 3 (IL-3) for growth in vitro $(2,6,8)$. Lymphoid cells are the usual target of A-MuLV in vivo (10). We have extended our knowledge from earlier observations to an IL-3-dependent, lymphoid precursor cell line, $\mathrm{Ba} / \mathrm{F} 3$, and have compared the abilities of different viruses encoding tyrosine-protein kinases to affect the IL-3 requirement of $\mathrm{Ba} / \mathrm{F} 3$ cells. In addition, we have examined the role of $c-m y c$ gene regulation in this process.

Clone $\mathrm{Ba} / \mathrm{F} 3$ was derived from murine bone marrow. Like similar clones, it expresses B-cell-specific surface glycoprotein B220 but has unrearranged immunoglobulin genes. It lacks T-cell (Thy1, Lyt), myeloid (MAC-1, Ia), and mature B-cell (Ig, Ia) antigens and strictly requires IL-3 for growth in vitro (7).

We infected $\mathrm{Ba} / \mathrm{F} 3$ cells with A-MuLV, helper Moloney murine leukemia virus (Mo-MuLV), or an A-MuLV derivative (V-SAB) in which A-MuLV gag sequences have been replaced with a $5^{\prime}$ fragment of the src gene (4). Cells were grown for 3 days in RPMI medium-10\% fetal calf serum-10\% WEHI-3 conditioned medium (as a source of IL-3) (7) and then were transferred to medium lacking IL-3. Uninfected and Mo-MuLV-infected cells died within $48 \mathrm{~h}$ without IL-3 supplementation. In contrast, $0.1 \%$ of the cells treated with A-MuLV or V-SAB viruses survived. Mass cultures were obtained within 2 weeks, and single cell clones were derived. The low percentage of IL-3-independent cells after A-MuLV or V-SAB infection reflects their poor infectibility. When $\mathrm{Ba} / \mathrm{F} 3$ cells were infected with the zip-neo retrovirus, which confers $\mathrm{G} 418$ resistance (1), only $0.1 \%$ of the cells survived G418 selection in IL-3-containing medium. IL-3-independent cell clones expressed the transforming protein of A-MuLV or V-SAB viruses detected by an in vitro kinase assay (Fig. 1A, lanes b and c). For this experiment, extracts of infected clones were immunoprecipitated with specific antisera, incubated with $\left[\gamma_{-}{ }^{32} \mathrm{P}\right] \mathrm{ATP}$, and electrophoresed through polyacrylamide gels. Because of residual nucleic acids in the extract, $\mathrm{P} 160^{\text {gag-abl }}$ appeared as a diffuse band near the top of the gel (Fig. 1A, lane b). This was also observed with different cell types infected with A-MuLV (data not shown).

Because $\mathrm{v}-a b l$ belongs to the protein-tyrosine kinase oncogene family $(12,13)$, we tested the effects of other

\footnotetext{
* Corresponding author.
}

members on the IL-3 requirement of $\mathrm{Ba} / \mathrm{F} 3$ cells. V-SRC, V-G $\Delta$ SRC, and V-GFPS recombinant viruses carry the src gene in a Mo-MuLV vector (V-SRC) or part of the src or fps genes fused to gag of A-MuLV (V-G $\Delta$ SRC and V-GFPS, respectively) (4).

Infections with viruses Mo-MuLV and A-MuLV were carried out in parallel. Two days after the removal of IL-3 from medium, no surviving cells were observed in the cultures infected with Mo-MULV or V-GFPS. By contrast, equal numbers of surviving cells were detected in the AMuLV, V-SRC, and V-G $\Delta$ SRC cultures, whereas clones of A-MuLV-infected cells rapidly divided in the absence of IL-3. Clones of V-SRC- and V-G $\Delta$ SRC-infected cells grew very poorly and appeared unhealthy. Rapid proliferation was achieved only after adding back a small amount of IL-3. All single cell clones derived from cultures infected with V-SRC and V-G $\Delta$ SRC expressed $\mathrm{p} 60^{\text {src }}$ and P78 ${ }^{\text {gag- } \Delta s r c}$, respectively (Fig. 1B, lanes $\mathrm{b}$ and $\mathrm{c}$; additional data not shown). $\left[{ }^{35} \mathrm{~S}\right]$ methionine labeling showed that these proteins were expressed at levels similar to those of P160 gag-abl (data not shown).

To allow selection of cells infected with a v-fps-containing virus, we inserted the coding sequence of V-GFPS into the DOL vector (provided by A. Korman) upstream of the neo gene driven by a simian virus 40 promoter. The resulting construct, pV-GFOL, was cotransfected with Mo-MuLV DNA onto NIH 3T3 cells, and foci were isolated in the presence of G418. Recovered virus from the best producer clone was used to infect $\mathrm{Ba} / \mathrm{F} 3$ cells. After $\mathrm{G} 418$ selection in the presence of IL-3, some of the resistant cells were grown in the absence of IL-3. These cells died within 2 days. Cells from the same culture kept in IL-3 expressed P125 gag-fps, albeit at a lower level than in the V-GFOL producer NIH $3 \mathrm{~T} 3$ clone (Fig. 1C, lanes b and c). Although P125gag-fps expression is usually low in fibroblasts infected with $\mathrm{V}$ GFOL virus, 5 to $10 \%$ of infected cells expressed high levels of the transforming protein (Fig. $1 \mathrm{C}$, lane b; additional data not shown). To attempt selection for high expression of $\mathrm{P} 125^{\text {gag-fps }}$ in V-GFOL-infected $\mathrm{Ba} / \mathrm{F} 3$ cells, we grew them without IL-3 for enough time periods to kill the majority of cells. After allowing the recovery of surviving cells in IL-3, we measured expression of P125 ${ }^{\text {gag-fps }}$ and the IL-3 requirement of the cells. In two separate experiments, the recovered population behaved like the parental culture (data not shown). Thus, the v-fps oncogene, in contrast to v-abl and 


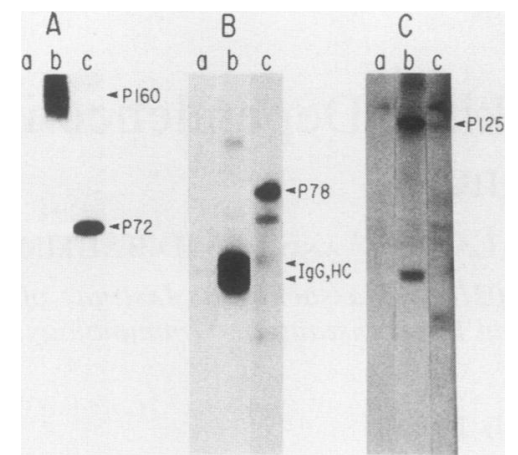

FIG. 1. In vitro kinase assay of immunoprecipitated viral proteins. Extracts of uninfected, v-abl-, v-src-, and v-fps-infected $\mathrm{Ba} / \mathrm{F} 3$ clones were immunoprecipitated with the indicated antisera, and kinase activity was assayed as previously described (5). (A) Anti- $a b l 587$ antiserum (11); lanes: a, Ba/F3; b, A-MuLV Ba/F3; c, V-SAB Ba/F3. (B) Anti-Rous sarcoma virus, TBR antiserum (v-src specific) (lanes $a$ and $b$ ) and anti-MuLV antiserum (lane c); lanes: a, $\mathrm{Ba} / \mathrm{F} 3$; $b, \mathrm{~V}-\mathrm{SRC} \mathrm{Ba} / \mathrm{F} 3$ (only phosphorylation of the immunoglobulin heavy chain by $\mathrm{p} 60^{\mathrm{v}-\mathrm{src}}$ was observed with tumor-bearing rabbit antiserum); c, V-G $\Delta S R V B a / F 3$. (C) Anti-MuLV antiserum; lanes: a, Ba/F3; b, V-GFOL NIH 3T3; c, V-GFOL Ba/F3. Panels A, B, and $C$ represent different gels.

$\mathrm{v}$-src, did not provide any growth advantage to $\mathrm{Ba} / \mathrm{F} 3$ cells in the absence of IL-3 (Table 1).

As an illustration of the differences in uninfected and A-MuLV-, V-SRC-, and V-GFOL-infected Ba/F3 cells, we titrated their IL-3 requirements. Cell proliferation was monitored by colorimetric assay (5) after a 24-h incubation (Fig. 2). A-MuLV-infected cells were totally IL-3 independent for growth. V-SRC-infected cell clones displayed an intermediate proliferation profile. V-GFOL-infected cells behaved similarly to uninfected cells (they were assayed in a separate experiment). These results are consistent with earlier observations (Table 1 ).

The mechanisms by which A-MuLV confers IL-3 independence remain uncertain. In agreement with other reports $(2$, 6,8 ), we could rule out autocrine stimulation in virus-

TABLE 1. IL-3 requirement of $\mathrm{Ba} / \mathrm{F} 3$ cells after viral infection ${ }^{a}$

\begin{tabular}{|c|c|c|c|c|}
\hline Virus $^{b}$ & $\begin{array}{l}\text { Transforming } \\
\text { gene }\end{array}$ & Titer & $\begin{array}{l}\text { Transforming } \\
\text { protein }\end{array}$ & $\begin{array}{c}\text { IL-3 } \\
\text { independence }\end{array}$ \\
\hline Mo-MuLV & $-^{d}$ & $1 \times 10^{7}$ & - & No \\
\hline A-MuLV & $v-a b l$ & $1 \times 10^{6}$ & $\mathrm{P} 160^{g a g-a b l}$ & Total \\
\hline V-SAB & v-abl & $1 \times 10^{6}$ & $\mathrm{P} 72^{\text {src-abl }}$ & Total \\
\hline V-SRC & $\mathrm{v}-s r c$ & $5 \times 10^{5}$ & p60 $0^{s r c}$ & Partial \\
\hline V-G $\Delta$ SRC & $\mathrm{v}-\Delta s r c$ & $5 \times 10^{6}$ & P78 gag-usrc & Partial \\
\hline V-GFPS & $\mathrm{v}-f p s$ & $5 \times 10^{5}$ & P125 $5^{g a g-f p s}$ & No \\
\hline Zip-neo ${ }^{e}$ & - & $1 \times 10^{6}$ & - & No \\
\hline V-GFOL ${ }^{e}$ & $v-f p s$ & $5 \times 10^{4}$ & $\mathrm{P} 125^{g a g-f p s}$ & No \\
\hline
\end{tabular}

${ }^{a} \mathrm{Ba} / \mathrm{F} 3$ cells $\left(10^{6}\right)$ were suspended in $3 \mathrm{ml}$ of growth medium containing $10 \%$ of WEHI-conditioned medium. Virus $(1 \mathrm{ml})$ was added to infect cultures Cells were incubated at $37^{\circ} \mathrm{C}$ overnight, washed, and replated in $10 \mathrm{ml}$ of growth medium containing 10\% WEHI-conditioned medium. After $24 \mathrm{~h}$, cells were washed twice and suspended in $10 \mathrm{ml}$ of growth medium without a source of IL-3. Medium was changed every 3 days, and cells were kept at a density of at least $5 \times 10^{3} / \mathrm{ml}$.

${ }^{b}$ All replication-defective viruses were pseudotyped with Mo-MuLV.

c Titers were measured on NIH 3T3 or XC cells. They are expressed as PFU, focus-forming units, or G418 CFU per milliliter.

${ }^{d}$ - None.

e For viruses containing the neo gene, the same infection protocol was used but $\mathrm{G} 418$ selection was applied first ( $1.5 \mathrm{mg}$ of $\mathrm{G} 418$ per $\mathrm{ml}$ ), in the presence of IL-3.

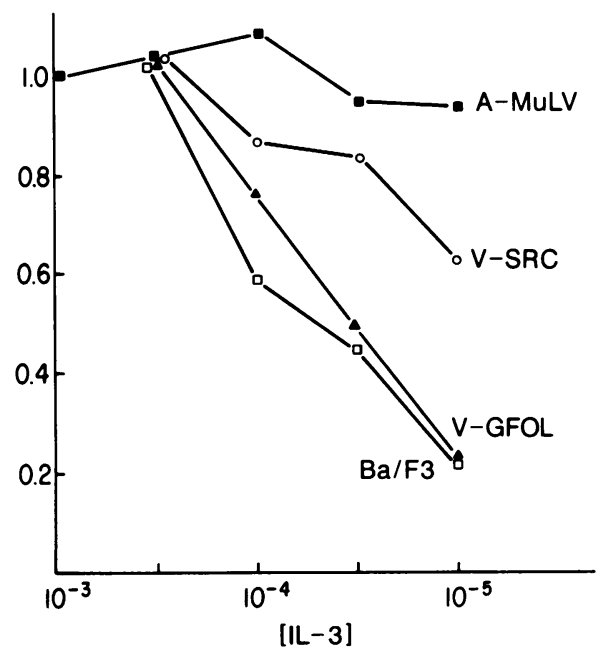

FIG. 2. Proliferation assay. Uninfected or virus-infected $\mathrm{Ba} / \mathrm{F} 3$ cells $\left(10^{4}\right.$ cells per well) were cultured for $24 \mathrm{~h}$ with IL-3 at the indicated dilutions of a stock solution. Proliferation was then measured in a colorimetric assay as previously described (5). Measurements have been normalized by dividing the optical density at a given IL-3 dilution by the density obtained at a $10^{-3}$ dilution of IL-3.

infected cells. Poly(A)-containing RNA $(2 \mu \mathrm{g})$ from infected and uninfected $\mathrm{Ba} / \mathrm{F} 3$ cells and WEHI cells was electrophoresed, transferred to nitrocellulose, and hybridized to an IL-3 specific probe (Fig. 3). Only WEHI cells expressed the 1-kilobase IL-3 mRNA (lane b) (14). Thus, IL-3 independence in infected $\mathrm{Ba} / \mathrm{F} 3$ cells did not result from endogenous synthesis of IL-3. Furthermore, neither conditioned medium nor freeze-thaw lysates from A-MuLV infectants supported growth of uninfected $\mathrm{Ba} / \mathrm{F} 3$ cells (data not shown). In addition, we found the majority of IL-3 receptors in infected cells available for binding and not occupied by a virusinduced growth factor that could compete for the IL-3 receptor (data not shown).

$\mathrm{v}-a b l$ might relieve IL-3 dependence of $\mathrm{Ba} / \mathrm{F} 3$ cells by inducing differentiation, presumably along the $\mathrm{B}$-cell lineage.

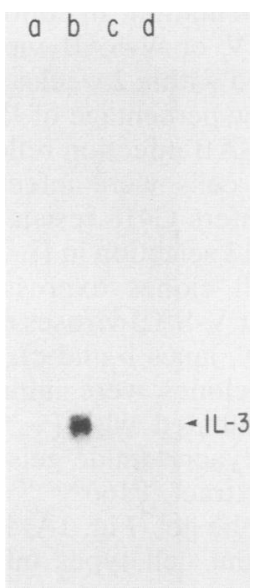

FIG. 3. Absence of IL-3 mRNA in V-SRC- or A-MuLV-infected $\mathrm{Ba} / \mathrm{F} 3$. Glyoxal-treated, poly(A)-containing RNA (4 $\mu \mathrm{g})$ were electrophoresed through a $1 \%$ agarose gel, transferred to nitrocellulose, and hybridized to an IL-3 cDNA probe. Lanes: a, Ba/F3; b, WEHI; c, V-SRC Ba/F3; d, A-MuLV Ba/F3. 


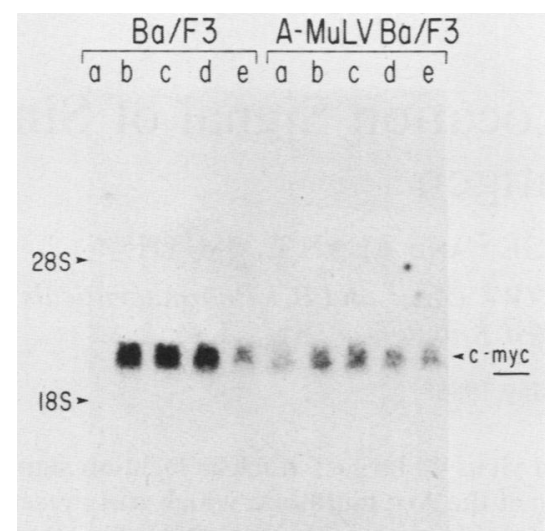

FIG. 4. Effect of IL-3 or A-MuLV infection on c-myc mRNA in BA/F3 cells. Total RNA was isolated from uninfected or A-MuLVinfected $\mathrm{Ba} / \mathrm{F} 3$ cells at the indicated times after IL-3 addition. For each time point, $20 \mu \mathrm{g}$ of RNA was treated with glyoxal, electrophoresed through a $1 \%$ agarose gel, transferred to nitrocellulose, and hybridized to a mouse c-myc cDNA probe. Rehybridizing the blot with a $\beta 2$-microglobulin probe revealed an equal amount of RNA in each lane (not shown). Migration of $28 S$ and 18S rRNA is shown. Lanes at hours indicated: a, 0; b, 1; c, 2; d, 6; e, 24.

No evidence of immunoglobulin heavy-chain rearrangement was detected (3), however, in DNA from v-abl-infected clones (data not shown).

Transformation by a virus expressing $\mathbf{v}-m y c$ alleviated IL-2 or IL-3 requirements in lymphokine-dependent cultured cells (9). To examine whether IL-3 independence is achieved by $\mathrm{v}-a b l$ via $c-m y c$ deregulation, we studied regulation of c-myc expression in uninfected and $\mathrm{A}-\mathrm{MuLV}$-infected $\mathrm{Ba} / \mathrm{F} 3$ cells. Cultures were maintained for $12 \mathrm{~h}$ in the absence of IL-3 (more than $75 \%$ of cells were still alive at that time). IL-3 was then added, total RNA was isolated at various time points, and c-myc transcripts were analyzed by Northern hybridization (Fig. 4). In the absence of IL-3, no c-myc transcription was detected in the nonproliferating, uninfected cells. Addition of IL-3 caused a transient increase in c-myc RNA that leveled off with time. In infected cells, IL-3 caused a small increase in c-myc RNA, after a time course similar to that seen for uninfected cells. In IL-3deprived, A-MuLV-infected cells, we detected a low level of $c-m y c$ RNA. This increase may reflect $\mathrm{v}-a b l$ action on c-myc expression or cell proliferation. Thus, c-myc RNA levels respond to $\mathrm{A}-\mathrm{MuLV}$ infection and to IL-3 in $\mathrm{Ba} / \mathrm{F} 3$ cells, but this response could not be directly uncoupled from proliferation. Other investigators have shown that v-myc-infected, IL-3-independent cells do not have detectable levels of c-myc RNA (9), suggesting that the presence of the v-myc protein could substitute for c-myc in growth. We do not have direct evidence that $\mathrm{v}-a b l$ causes IL-3 independence via a specific increase in the c-myc message, although we cannot rule it out.

That v-abl acts on a wide range of IL-3-dependent, hemopoietic cells is well documented $(2,6,8)$. $\mathrm{v}$ - $a b l$ must act on a common denominator shared by these cells, possibly by subverting the same pathway used by IL-3. It is therefore important to address the substrate specificity of $\mathrm{v}$ - $a b l$ protein among tyrosine kinases as a key to unlocking the cellular events leading to IL-3 independence.

We thank Alan Korman (Whitehead Institute, Cambridge, Mass.) for his gift of pDOL plasmid. We are grateful to Bob Finkelstein for his critical reading of the manuscript and especially to Nancy Andrews for valuable suggestions on the manuscript and critical discussion of the experiments.

This work was supported by grant CA38497 from the National Cancer Institute. B.M.-P. is a recipient of a fellowship from the Helen Hay Whitney Foundation; G.N. was supported by Howard Hughes Medical Institute, Boston, Mass.

\section{LITERATURE CITED}

1. Cepko, C. L., B. E. Roberts, and R. C. Mulligan. 1984. Construction and application of a highly transmissable murine retrovirus shuttle vector. Cell 37:1053-1062.

2. Cook, W. D., D. Metcalf, N. A. Nicola, A. W. Burgess, and F. Walker. 1985. Malignant transformation of a growth factordependent myeloid cell line by Abelson virus without evidence of an autocrine mechanism. Cell 41:677-683.

3. DePinho, R., K. Kruger, N. Andrews, S. Lutzker, D. Baltimore, and F. W. Alt. 1984. Molecular basis of heavy-chain class switching and switch region deletion in an Abelson virustransformed cell line. Mol. Cell. Biol. 4:2905-2910.

4. Mathey-Prevot, B., and D. Baltimore. 1985. Specific transforming potential of oncogenes encoding protein-tyrosine kinases. EMBO J. 4:1769-1774.

5. Mosmann, T. 1983. A rapid and quantitative colorimetric assay for cellular proliferation: application to lymphokines assays, mitogen stimulations and complement-mediated cytotoxicity. J. Immunol. Methods 65:55-63.

6. Oliff, A., O. Agranovsky, M. D. McKinney, V. V. V. S. Murty, and R. Bauchwitz. 1985. Friend murine leukemia virusimmortalized myeloid cells are converted into tumorigenic cell lines by Abelson leukemia virus. Proc. Natl. Acad. Sci. USA 82:3306-3310.

7. Palacios, R., and M. Steinmetz. 1985. IL-3 dependent mouse clones that express B220 surface antigen, contain Ig genes in germ-line configuration, and generate $B$ lymphocytes. Cell 41:727-734.

8. Pierce, J. H., P. P. Di Fiore, S. A. Aaronson, M. Potter, J. Pumphrey, A. Scott, and J. H. Thle. 1985. Neoplastic transformation of mast cells by Abelson-MuLV: abrogation of IL-3 dependence by a nonautocrine mechanism. Cell 41:685-693.

9. Rapp, U. R., J. L. Cleveland, K. Brightman, A. Scott, and J. N. Ihle. 1985. Abrogation of IL-3 and IL-2 dependence by recombinant murine retroviruses expressing v-myc oncogenes. Nature (London) 317:434-438.

10. Rosenberg, N., D. Baltimore, and C. D. Scher. 1975. In vitro transformation of lymphoid cells by Abelson murine leukemia virus. Proc. Natl. Acad. Sci. USA 72:1932-1936.

11. Wang, J. Y. J. 1985. Isolation of antibodies for phosphotyrosine by immunization with a v-abl oncogene-encoded protein. Mol. Cell. Biol. 5:3640-3643.

12. Wang, J. Y. J., F. Ledley, S. Goff, R. Lee, M. Paskind, Y. Groner, and D. Baltimore. 1984. The mouse c-abl locus: molecular cloning and characterization. Cell 36:349-356.

13. Witte, O. N., A. Dasgupta, and D. Baltimore. 1980. Abelson murine leukemia virus protein is phosphorylated in vitro to form phosphotyrosine. Nature (London) 283:826-831.

14. Yokota, T., F. Lee, D. Rennick, C. Hall, N. Arai, T. Mosmann, G. Nabel, H. Cantor, and K.-I. Arai. 1984. Isolation and characterization of a mouse cDNA clone that expresses mastcell growth-factor activity in monkey cells. Proc. Natl. Acad. Sci. USA 81:1070-1074. 